\title{
The Impact of Innovation and Knowledge Management on Enterprises Revenues in Serbia
}

Submitted 14/10/21, 1st revision 12/11/21, 2nd revision 28/12/21, accepted 05/02/22

\author{
Ilir Morina ${ }^{1}$
}

\begin{abstract}
:
Purpose: There is a significant and positive relationship between knowledge management and the innovation of enterprises. On the other hand, innovations enable enterprises to bring new and improved products and services in the market and thus to meet customers' needs better and thoroughly, to gain loyal customers, to increase sales of products and services, to substitute outdated products, to increase their income, to improve their market share, to increase their competitive advantage, to conquer new market segments and new markets, to improve their performance, and as a result, positively affect to the economic development of the country in which they operate. This paper aims to show the importance of knowledge management and innovation for the performance of enterprises in Serbia.

Design/Methodology/Approach: To determine the extent to which innovations are present in companies in Serbia and whether they are essential for the performance of companies (and especially for their revenues), this paper uses secondary data sources from various national and international bodies and organizations. For that purpose, first, the number and size of enterprises in Serbia are determined, then the share of innovative enterprises in the total number of enterprises, and finally, the share of innovation revenues in the total revenues of innovative enterprises.

Findings: Innovation and knowledge management are of great importance for companies' revenues in Serbia, regardless of their size and activity. Recognizing that importance, companies in Serbia have increased their innovative activity in recent years. That progress can be seen from the data of the European Innovation Scoreboard - EIS.

Practical Implications: This paper has proved the importance of innovation and knowledge management for corporate performance and can positively influence companies to increase their innovative activities to achieve more excellent performance and thus contribute to economic development in the country in which they operate.

Originality/Value: This paper has proved the importance of innovation and knowledge management for the performance of companies in Serbia (and especially for increasing their revenues).
\end{abstract}

Keywords: Innovation, Knowledge Management, Performance, Enterprises, Revenues, Serbia.

JEL Code: O31, O32.

Research type: Research article.

${ }^{1}$ Ph.D., University MB-Faculty of Business and Law-Beograd. Direction: Management, ilirmorina@hotmail.com; 


\section{Introduction}

Knowledge is a key value and the main driver for the organizational survival and success of enterprises of any size and industry. It is not the sole element for an organization's survival, but it is the most important because it supports all other elements. For this reason, the managers of the enterprises are very deeply involved in understanding knowledge and developing knowledge management processes and systems to exploit opportunities that it offers to the competitive advantage and performances of their companies.

\section{Literature Review}

\subsection{Defining Knowledge Management}

In the last decade of the twentieth century, knowledge management has evolved from consultancy to academic science. It has become a specialized management field like other branch sciences through knowledge, skills, and abilities. Knowledge management is a relatively young discipline with its roots in numerous disciplines.

In the literature, there are many different definitions for the concept of knowledge management given from academics, practitioners, governments, profits, and not profits sectors. However, the most common definitions of knowledge management are knowledge, organization, process, information, use, share, create, and manage.

According to Davenport and Prusak (2000), knowledge management is managing the corporation's knowledge through a systematically and organizationally specified process for acquiring, organizing, sustaining, applying, sharing, and renewing both the tacit and explicit knowledge. Of employees to enhance organizational performance and create value. Knowledge management is the creation, transfer, and exchange of organizational knowledge to achieve a competitive advantage (Girard and Girard, 2015).

Knowledge management is the process through which organizations generate value from their intellectual and knowledge-based assets (Levinson, 2007). The process of connecting people to people and people to information to create a competitive advantage (Shim et al., 2012). The facilitation and support of processes for creating, sustaining, sharing, and renewing of organizational knowledge to generate economic wealth, create value, or improve performance (Allee, 1997).

Knowledge management is an integrated systematic approach which, when applied to an organization, enables the optimal use of timely, accurate and relevant information, it also facilitates knowledge discovery and innovation, fosters the development of a learning organization, and enhances understanding by integrating all sources of information, as well as individual and collective knowledge and experience (Gamblin, 
2013). Knowledge management is a mechanism through which innovation complexity can be addressed (Cavusgil et al., 2003).

\subsection{Defining Innovation}

Many authors consider that innovation is the principal driver of competitiveness and a key factor for any business's survival, primarily when the enterprises operate in a changing and competitive environment. It encompasses a broad research field that analyses multiple aspects. There are different terms to refer to it explains concept's complexity.

The origin of the word innovation comes from the Latin words "innovation" or "innovator." Both words mean to "renew or to make something new" (Norrman, 2008). Schumpeter used the term innovation for the first time at the beginning of the 20 th century. Schumpeter defined innovations as "product, process and organizational changes that do not necessarily originate from new scientific discoveries but may arise from a combination of already existing technologies and their application in a new context" (Urbancova, 2013).

Innovation is defined as "the implementation of a new or significantly improved product (goods or services) or process, new marketing methods, or a new organizational method in business practices, workplace organization, or external relations" (U.S. Census Bureau, 2006).

Innovation is a complex process that brings ideas to market in the form of new or improved products or services. This process consists of two parts, which are not necessarily sequential, although they are linked paths between them in a back-andforth direction. One part is specialized on the know-how, and the other is devoted primarily to the application as a process, a product, or a service. In both parts, they incorporate new advantages to the market (Castro and de Lucio, 2001).

The innovation process comes from different sources, and it can be classified according to a range of criteria. Product innovation can be applied to a good or service; it involves changes in working methods or production functions. Innovation is not limited only to the product or its manufacturing process, but it involves many other aspects affecting company decision-making. Table 1 presents the multifaceted concept depending on the direction applied.

Table 1. Innovation as a multifaceted concept

\begin{tabular}{|c|c|}
\hline Depending on the object & Depending on their relevance \\
$-\quad$ Product & - Incremental \\
$-\quad$ Process & - Radical \\
\hline Depending on the field & Depending on their origin \\
$-\quad$ Technology & - R\&D \\
$-\quad$ Organizational & Incorporation \\
\hline
\end{tabular}




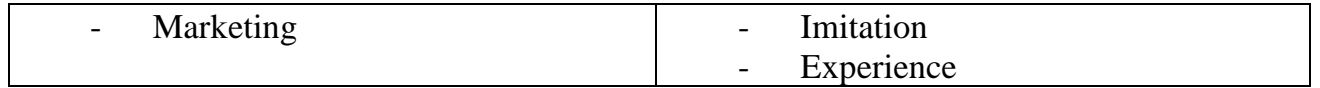

Source: Rojas et al., 76.

The literature is full of attempts to categorize different levels and types of innovation. Some of the types of innovation are following.

Marketing innovation is concerned with improving the mix of target markets and how chosen markets are best served. Its purpose is to identify better (new) potential markets and better (new) ways to serve target markets. Organizational innovation means the innovation of business models, management techniques and strategies, and organizational structures. Process innovation is implementing a new or significantly improved production process, distribution method, or support activity for goods or services. Thus, a pure process innovation changes how a product is made without changing itself. The literature has identified various forms of process innovation, organizational innovation, supply chain innovation, marketing innovation, and business model innovation.

Product innovation is defined as goods or services which is either new or significantly improved concerning their fundamental characteristics, technical specifications, incorporated software, or other immaterial components, intended uses, or userfriendliness. A pure product innovation creates a new or improved product for sale without any change in the production process.

Radical innovation means significantly different changes to products, services, or processes - "do what we do differently." Radical innovation describes improvements that fundamentally alter the character of a product or process. This type of innovation establishes a new dominant design and hence, a new set of core design concepts embodied in components that are linked together in a new architecture. Radical innovation creates specific challenges for established firms since it destroys the usefulness of their existing capabilities.

Incremental innovation is known as minor improvements to existing products, services, or processes - "doing what we do but better." Incremental innovation describes the steady stream of improvements to a particular product or process which do not change the character of that product or process in any fundamental way. This type of innovation refines and extends an established design. Improvement occurs in individual components, but the underlying core design concepts and the linkage between them. This tends to reinforce the competitive positions of established firms since it builds on their core competencies.

Discontinuous innovation - radical innovations which change the "rules of the game" and open a new game in which new players are often at an advantage. Modular innovation changes the core design of one or more components but does not change the overall product architecture. This type of innovation will require new knowledge 
for one or more components, but the architectural knowledge remains the same. This is a competence destroying innovation since new knowledge of a new component must be acquired, and the knowledge of the replaced component is no longer an asset.

Component innovation - changes at the level of components in a more extensive system. Architecture innovation - changes in the whole system. The essence of architectural innovation is reconfiguring an established system to link together components in a new way. Architectural innovation does not mean that components remain unchanged, but they are changed so that it opens new ways of linkage between the components. This change is so tiny that the core concept behind the changed component is the same, and the associated scientific and engineering knowledge remains the same.

Position innovation means changes in the context in which the product/services are introduced. Paradigm innovation means changes in the underlying mental models that frame the organization. According to Tiwari and Buse (2007), a simplified innovation process has several systematic steps such as requirement analysis, idea generation, idea evaluation, project planning, product development, product testing, and product marketing may overlap each other.

Figure 1. Three phases of a simplified innovation process

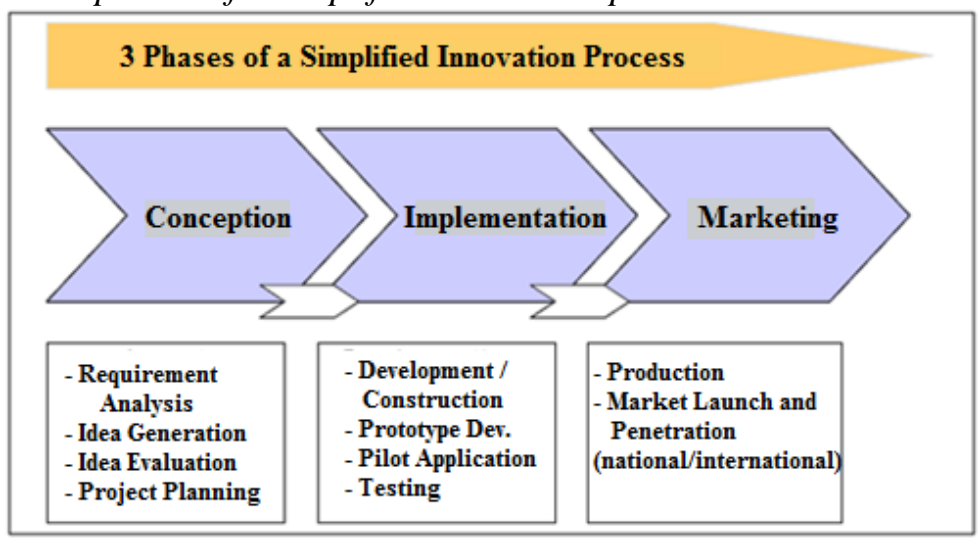

Source: Tiwari and Buse (2007).

Various factors encourage an organization to innovate. These factors can be summarized as follows (Sullivan, 2008):

- Emerging technologies,

- Competitor actions,

- New ideas from customers, strategic partners, and employees,

- Emerging changes in the external environment.

Innovative products will help firms to strength their competitive position in home as well as international markets. This necessitates innovation efforts to bring new and/or 
better products into the market enable more efficient and cost-effective production, distribution, and after-sales services.

\subsection{The Importance of Knowledge Management of Innovation}

The importance of knowledge management and its relationship to innovation is widely acknowledged. Many scholars have explored the relationship between knowledge management and innovation (Carneiro, 2000; Abraham, 2008; Gloet and Terziovski, 2004; Cavusgil et al., 2003).

Carneiro (2000) investigates the relationship between knowledge management, levels of innovation, and competitiveness in organizations and suggests that knowledge management positively influences innovation and competitiveness. Abraham (2008) highlights that the primary goal of knowledge management is innovation.

Gloet and Terziovski (2004) have concluded a significant and positive relationship between knowledge management practices and organizations' innovation performance. According to them, organizations should strive for an integrated approach towards knowledge management, which assists in building a corporate culture to maximize innovation performance leading to competitive advantage.

Cavusgil et al. (2003) declare that knowledge management is a mechanism to address innovation complexity. According to Du Plessis (2007), knowledge management has crucial importance in the innovation process for the following reasons:

- Knowledge management assists in creating tools, platforms and processes for tacit knowledge creation, sharing and leverage in the organization, which plays an important role in the innovation process;

- Knowledge management assists in converting tacit knowledge to explicit knowledge;

- Knowledge management facilitates collaboration in the innovation process;

- Knowledge management ensures the availability and accessibility of both tacit and explicit knowledge used in the innovation process, using knowledge organization and retrieval skills and tools such as taxonomies;

- Knowledge management ensures the flow of knowledge used in the innovation process;

- Knowledge management provides platforms, tools and processes to ensure integration of an organization's knowledge base;

- Knowledge management assists in identifying gaps in the knowledge base and provides processes to fill in the gaps in order to aid innovation;

- Knowledge management assists in building competencies required in the innovation process;

- Knowledge management provides organizational context to the body of knowledge in the organization; 
- Knowledge management assists in steady growth of the knowledge base through gathering and capturing of explicit and tacit knowledge;

- Knowledge management provides a knowledge-driven culture within which innovation can be incubated.

\subsection{The Role of Innovations on the Enterprises Competitiveness}

Globalization of the markets and increasing international competition force enterprises to search for new, innovative, flexible, and imaginative ways to survive. Therefore, the above statement provides a relationship between innovation and enterprises survival.

According to Urbancova (2013), organizations can gain competitive advantage only by managing effectively for today while simultaneously creating innovation for tomorrow. She suggested that there is perhaps no more pressing managerial problem than the sustained innovation management. According to her visionary leadership and people, structures, and values are essential factors that affect whether an organization realizes benefits from innovation. Innovation is still seen as a critical driver of economic performance.

In the World Bank report (2009), innovation has been viewed as vital in ensuring competitive advantage by organizations and long-term loyalty. An important issue facing enterprises worldwide is continuous improvement. In today's markets, the inputs of customers and their fast-changing needs are imperative for enterprises to improve their business continuously. Enterprises need to consider continuously improving production costs, delivery schedules, manufacturing skills, supplier relationships, and productivity in all practices. They constantly experience shortages in capital to employee skills to improve production capacity, making it necessary to continuously improve their production strategies with customized products and process-focused operations.

Moreover, enterprise operations should embrace competitive priorities of low production costs, fast on-time deliveries, high-quality products, and customer services. Enterprises that have adapted their production systems to be flexible and their costs and prices competitive will compete and capture increased market share. This signifies the importance of innovation in enhancing loyalty and long-term customer value. The creative input determines the innovation output, i.e., the transformation of input into output. The creative output is related to the firm performance. Creative output, via firm performance, would affect innovation expenditures. The overall economic performance of a firm would affect all three stages of a firm's innovation process. Total sales growth would be higher for innovating firms than for non-innovating firms, etc. Innovation boosted the competitiveness of enterprises. 
Innovations enable enterprises to bring new and improved products and services in the market and thus to meet customers' needs better and thoroughly, to gain loyal customers, to increase sales of products and services, to substitute outdated products, to increase their income, to improve their market share, to increase their competitive advantage, to conquer new market segments and new markets, to improve their performance, and as a result, positively affect to the economic development of the country in which they operate.

\section{Research Methodology}

To determine the extent to which innovations are present in companies in Serbia and whether they are essential for the performance of companies (and especially for their revenues), this paper is used secondary data sources from various national and international bodies and organizations. For that purpose, first, the number and size of enterprises in Serbia are determined, then the share of innovative enterprises in the total number of enterprises, and finally, the share of innovation revenues in the total revenues of innovative enterprises.

\section{Results}

In 2018 in Serbia were registered 376,382 enterprises of which 362,106 micro enterprises, 11,219 small enterprises, 2,517 medium enterprises and 540 large enterprises.

Table 2. Number of enterprises, by size classes in Serbia, 2018

\begin{tabular}{|l|r|r|}
\hline Enterprises by size & Number of enterprises & \multicolumn{1}{c|}{} \\
\hline Micro (0-9) & 362106 & 96,2 \\
\hline Small (10-49) & 11219 & 3,0 \\
\hline Medium 50-249) & 2517 & 0,7 \\
\hline Large (250 or more) & 540 & 0,1 \\
\hline Total & $\mathbf{3 7 6 ~ 3 8 2}$ & $\mathbf{1 0 0}$ \\
\hline
\end{tabular}

Source: OECD.org.

Table 2. Statistic

\begin{tabular}{|l|l|}
\hline Min & 540 \\
\hline Max & 362106 \\
\hline Range & $\mathrm{R}=361566$ \\
\hline Size & $\mathrm{n}=4$ \\
\hline Sum & 376382 \\
\hline Mean & 94095.5 \\
\hline Median & 6868 \\
\hline Mode & 2517.540 \\
\hline Standard Deviation & 178733.876 \\
\hline Coefficient of Variation & 1.89949441 \\
\hline
\end{tabular}

Source: Own creation. 
Table 3. Frequency table

Source: Own creation.

\begin{tabular}{|c|c|c|}
\hline Value & Frequency & Frequency $\%$ \\
\hline 540 & 1 & 25,00 \\
\hline 2517 & 1 & 25,00 \\
\hline 11219 & 1 & 25,00 \\
\hline 362106 & 1 & 25,00 \\
\hline
\end{tabular}

The number of innovative enterprises in Serbia is continuously increasing over time. For example, in 2012, $44.60 \%$ of the enterprises in Serbia were innovative, and in 2018 their share increased to $50.21 \%$. In $2018,47.65 \%$ of the total number of small enterprises, $61.83 \%$ of medium enterprises, $69.10 \%$ of large enterprises, $56.64 \%$ of manufacturing enterprises, and $47.90 \%$ of service enterprises were innovative in Serbia. The biggest innovators are large enterprises, followed by medium-sized enterprises and small enterprises.

Table 4. Innovative enterprises (\%)

\begin{tabular}{|l|c|c|c|c|}
\hline & 2012 & 2014 & 2016 & 2018 \\
\hline Innovative enterprises - total & 44,60 & 40,50 & 41,20 & 50,21 \\
\hline Small enterprises (\%) & 40,80 & 37,40 & 38,20 & 47,65 \\
\hline Medium enterprises (\%) & 55,00 & 52,70 & 54,40 & 61,83 \\
\hline Large enterprises (\%) & 66,20 & 68,10 & 66,30 & 69,10 \\
\hline Productive enterprises (\%) & 48,70 & 40,60 & 47,30 & 56,64 \\
\hline Service enterprises (\%) & 42,40 & 40,40 & 38,90 & 47,90 \\
\hline
\end{tabular}

Source: stat.gov.rs.

The most significant percentage of the total number of innovative enterprises in Serbia in $2016(33.4 \%)$ are technological innovators, and the remaining percentage of innovative enterprises are non-technological enterprises. In large enterprises, 56.8\% of the total innovators were technological innovators (innovators of products and processes), and $56.1 \%$ were non-technological innovators (innovators of organization and marketing). Of the entire innovative medium-sized enterprises, $43.8 \%$ were technological innovators, and $42.4 \%$ were non-technological innovators. The situation is the same with small innovative enterprises (30.9\% are technological innovators, and $27.3 \%$ are non-technological innovators).

Table 5. Structure of the type of innovation in the total innovative activities of innovator companies (\%)

\begin{tabular}{|c|r|l|l|l|l|}
\hline $\begin{array}{l}\text { Enterprises } \\
\text { by size }\end{array}$ & $\begin{array}{l}\text { Innovator } \\
\text { enterprises }\end{array}$ & $\begin{array}{l}\text { Technological } \\
\text { innovators } \\
\text { (products and } \\
\text { processes) }\end{array}$ & $\begin{array}{l}\text { Non- } \\
\text { technological } \\
\text { innovators } \\
\text { (organization } \\
\text { and } \\
\text { marketing) }\end{array}$ & $\begin{array}{l}\text { Enterprises - } \\
\text { technological } \\
\text { and non- } \\
\text { technological } \\
\text { innovators }\end{array}$ & $\begin{array}{l}\text { Enterprises } \\
\text { without } \\
\text { innovation }\end{array}$ \\
\hline Total & 41,2 & 33,4 & 30,2 & 22,4 & 58,8 \\
\hline
\end{tabular}




\begin{tabular}{|c|r|r|r|r|r|}
\hline Small & 38,2 & 30,9 & 27,3 & 20,0 & 61,8 \\
\hline Medium & 54,4 & 43,8 & 42,4 & 31,9 & 45,6 \\
\hline Large & 66,3 & 56,8 & 56,1 & 46,6 & 33,6 \\
\hline
\end{tabular}

Source: Stat.gov.rs.

The most common type of innovation in innovative companies in 2016 are innovations in products and services $(26.9 \%)$, followed by, innovations in the organization of the enterprise (24.2\%), marketing innovations (22.3\%), and process innovations $(21.0 \%)$. Abandoned innovations or innovations still in progress represent $14.3 \%$ of the total number of innovations.

Analyzed by territorial distribution, the most significant percentage of innovations in products and services $(28,4 \%)$, process innovations $(25,0 \%)$, and marketing innovations $(25,0 \%)$ are represented in the region of Sumadija and Western Serbia, and innovations in the organization of enterprises $(25,0 \%)$ in the region of Belgrade.

Table 6. Representation of the types of innovations in the enterprise's innovators by territory (\%)

\begin{tabular}{|c|c|c|c|c|c|c|}
\hline \multirow[t]{2}{*}{ Territory } & \multicolumn{6}{|c|}{ Type of innovation } \\
\hline & $\begin{array}{l}\text { Product } \\
\text { /service } \\
\text { innovat } \\
\text { ion }\end{array}$ & $\begin{array}{l}\text { Process } \\
\text { innovati } \\
\text { on }\end{array}$ & $\begin{array}{l}\text { Abandoned } \\
\text { innovation } \\
\text { or still in } \\
\text { progress }\end{array}$ & $\begin{array}{l}\text { Innovations in } \\
\text { the } \\
\text { organization } \\
\text { of the } \\
\text { company }\end{array}$ & $\begin{array}{l}\text { Mark } \\
\text { eting } \\
\text { innov } \\
\text { ations }\end{array}$ & $\begin{array}{l}\text { non- } \\
\text { innov } \\
\text { ators }\end{array}$ \\
\hline Republic of Serbia & 26,9 & 21,0 & 14,3 & 24,2 & 22,3 & 58,8 \\
\hline Serbia-north & 26,4 & 19,7 & 14,9 & 24,9 & 21,7 & 58,7 \\
\hline Belgrade region & 27,2 & 21,0 & 16,1 & 25,0 & 22,0 & 58,7 \\
\hline $\begin{array}{l}\text { Region of } \\
\text { Vojvodina }\end{array}$ & 25,1 & 17,4 & 12,8 & 24,9 & 21,3 & 58,8 \\
\hline Serbia - south & 28,0 & 24,2 & 13,1 & 22,6 & 23,4 & 58,9 \\
\hline $\begin{array}{l}\text { Sumadija region } \\
\text { and western } \\
\text { Serbia }\end{array}$ & 28,4 & 25,0 & 13,6 & 22,7 & 25,0 & 57,6 \\
\hline $\begin{array}{l}\text { Region of } \\
\text { Southern and } \\
\text { Eastern Serbia }\end{array}$ & 27,4 & 22,8 & 12,3 & 22,3 & 20,9 & 61,1 \\
\hline
\end{tabular}

Source: Stat.gov.rs.

The share of revenues from product / service innovations that were new to the market is $5.8 \%$, and those that were new to the business entity $9.3 \%$, in relation to the total revenue of innovator enterprises. The share of revenues from innovation of products / services that are new for the market and new for the enterprise, in the total revenues of the innovating enterprises (according to their size), is shown in Table 7. 
Table 7. Share of product / service innovation revenue in total revenue of innovator companies (in \%)

\begin{tabular}{|c|c|c|c|c|}
\hline $\begin{array}{l}\text { Type of product } \\
\text { innovation }\end{array}$ & Total & Small & Medium & Large \\
\hline Total & 100,0 & 100,0 & 100,0 & 100,0 \\
\hline $\begin{array}{l}\text { Innovations in } \\
\text { products / services } \\
\text { new for the market }\end{array}$ & 5,8 & 6,8 & 2,7 & 6,4 \\
\hline $\begin{array}{l}\text { Innovations in } \\
\text { products / services } \\
\text { new for the } \\
\text { company }\end{array}$ & 9,3 & 8,4 & 6,5 & 10,1 \\
\hline $\begin{array}{l}\text { From unproven } \\
\text { products / services }\end{array}$ & 84,9 & 84,8 & 90,8 & 83,5 \\
\hline
\end{tabular}

Source: Stat.gov.rs.

Recognizing the enormous importance of innovation for enterprises' performance, companies in Serbia have sought to increase their innovative activity in recent years. That progress can be seen from the data of the European Innovation Scoreboard EIS.

According to the data of the European Innovation Scoreboard 2021, Serbia is an emerging innovator. Over time, performance in Serbia relative to the EU has increased. Structural differences with the EU are shown in table 8, including, compared to the European Innovation Scoreboard 2020, new information on different types of (innovating) enterprises (Innovation profiles).

According to those data, Serbia has above-average shares of in-house product innovators without market novelties, innovators that do not develop innovations themselves, in-house product innovators with market novelties, and non-innovators with the potential to innovate.

Table 8. Differences between EU and Serbia among innovation profiles of the enterprises 2020

\begin{tabular}{|l|r|r|}
\hline \multicolumn{1}{|c|}{ Innovation profiles } & Serbia & EU \\
\hline In-house product innovators with market novelties & 11.5 & 10.7 \\
\hline In-house product innovators without market novelties & 16.5 & 12.3 \\
\hline In-house business process innovators & 6.7 & 11.0 \\
\hline Innovators that do not develop innovations themselves & 18.9 & 11.6 \\
\hline Innovation active non-innovators & 0.1 & 3.3 \\
\hline Non-innovators with potential to innovate & 21.6 & 19.9 \\
\hline Non-innovators without disposition to innovate & 24.7 & 31.3 \\
\hline
\end{tabular}

Source: European Innovation Scoreboard 2021. 
According to this Scoreboard, Serbia's strengths are innovators, firm investments, and employment impacts. The top-3 indicators include Non-R\&D innovation expenditures, product innovators, and employment in innovative enterprises. In the last two years, the improvement in innovation performance is the result of improved performance for broadband penetration, venture capital, product and business process innovators, design applications, and employment in innovative enterprises.

\section{Conclusions}

Knowledge is a key value and the main driver for the organizational survival and success of enterprises of any size and industry. For this reason, the managers of the enterprises are very deeply involved in understanding knowledge and developing knowledge management processes and systems to exploit opportunities that it offers to the competitive advantage and performances of their companies. In the last decade of the twentieth century, knowledge management has evolved from consultancy to academic science.

There is a significant and positive relationship between knowledge management and the innovation of enterprises. On the other hand, innovations enable enterprises to bring new and improved products and services in the market and thus to meet customers' needs better and thoroughly, to gain loyal customers, to increase sales of products and services, to substitute outdated products, to increase their income, to improve their market share, to increase their competitive advantage, to conquer new market segments and new markets, to improve their performance, and as a result, positively affect to the economic development of the country in which they operate.

Recognizing the enormous importance of innovation for enterprises' performance and economic development, companies in Serbia have sought to increase their innovative activity in recent years. That progress can be seen from the data of the European Innovation Scoreboard - EIS.

According to the data of the European Innovation Scoreboard 2021, Serbia is an emerging innovator. Over time, performance in Serbia relative to the EU has increased.

\section{References:}

Allee, V. 1997. The Knowledge Evolution: Expanding Organizational Intelligence 1st Edition. Butterworth-Heinemann, ISBN-10: 075069842X, ISBN-13: 9780750698429.

Ayandibu, A.O. 2020. Reshaping Entrepreneurship Education with Strategy and Innovation. IGI Global.

Carneiro, A. 2000. How does knowledge management influence innovation and competitiveness? Journal of Knowledge Management, 4(2). DOI: $10.1108 / 13673270010372242$. 
Cavusgil, S.T., Calantone, T.R., Zhao, Yu. 2003. Tacit knowledge transfer and firm innovation capability, Journal of Business \& Industrial Marketing

Chung, H.M., Au, K. 2021. Succession and Innovation in Asia's Small and Medium-Sized Enterprises. Palgrave Macmillan.

Drucker, P. 2015. Innovation and Entrepreneurship - Practice and Principles. Butterworth Heinemann.

Du Plessis, M. 2007. The role of knowledge management in innovation. Journal of Knowledge Management, 11(4), 20-29. DOI: 10.1108/13673270710762684.

Ferreira, C.L., Pilatti, L.A. 2013. Analysis of the Seven Dimensions of Knowledge Management in Organizations. Journal of Technology Management \& Innovation, 8, Special Issue ALTEC.

Foss, N.J., Saebi, T. 2015. Business Model Innovation - The Organizational Dimension. Oxford University Press.

Gamblin, E.W. 2013. Knowledge and the Defence Enterprise: Developing a Culture of "Need to Share" for Organizational Success. Canadian Forces College - Collège Des Forces Canadiennes JCSP 40 - Pcemi 40, 2013-2014.

Girard, J.P., Girard, J.L. 2015. Defining knowledge management: Toward an applied compendium. Online Journal of Applied Knowledge Management, 3(1), 1-20.

Gloet, M., Terziovski, M. 2004. Exploring the relationship between knowledge management practices and innovation performance. Journal of Manufacturing Technology Management, 15(5), 402-409. DOI: 10.1108/17410380410540390.

Gonzalez, R.V.D., Martins, M.F. 2017. Knowledge Management Process: A Theoreticalconceptual Research, Gestao \& Producao, São Carlos, 24(2), 248-265. http://dx.doi.org/10.1590/0104-530X0893-15.

Hajric, E. 2018. Knowledge Management System and Practices - A Theoretical and Practical Guide for Knowledge Management in Your Organization. Kindle Edition, Amazon.

Jin, S.H., Choi, S.O. 2019. The Effect of Innovation Capability on Business Performance: A Focus on IT and Business Service Companies. Sustainability, 11(19), 5246, DOI: $10.3390 /$ su11195246.

Kovaci, I., Tahiri, A., Bushi, F., Zhubi, M. 2021. Organization as a Function of Management and the Types of Organizational Structures that Apply in SMEs in Kosovo. Quality Access to Success, 22(181).

Levine, S.S., Prietula, M. 2012. How knowledge transfer impacts performance: a multilevel model of benefits and liabilities. Organization Science, 23(6), 1748-1766. http://dx.doi.org/10.1287/orsc.1110.0697.

Levinson, M. 2007. Knowledge Management Definition and Solutions. CIO Magazine.

Martín-de-Castro, G. 2015. Knowledge management and innovation in knowledge-based and high-tech industrial markets: the role of openness and absorptive capacity. Industrial Marketing Management, 47, 143-146.

Masouras, A., Maris, G., Kavoura, A. 2020. Entrepreneurial Development and Innovation in Family Businesses and SMEs. IGI Global.

Mohapatra, S., Agrawal, A., Satpathy, A. 2018. Designing Knowledge Management-Enabled Business Strategies: A Top-Down Approach. Springer International Publishing.

North, K., Kumta, G. 2018. Knowledge Management - Value Creation Through Organizational Learning. Second Edition, Springer.

Ordonez de Pablos, O. 2020. Innovative Management and Business Practices in Asia. IGI Global.

Shim, K.J., Siegel, G.J., Shim, I.A. 2012. CFO Fundamentals: Your Quick Guide to Internal 
Controls, Financial Reporting, IFRS, Web 2.0, Cloud Computing, and More. John Wiley \& Sons, pp. 784.

Tahiri, A., Kovaci, I. Krasniqi, A. 2020. Human Resource Management, Performance Management and Employee Performance Appraisal by SME Managers in Kosovo. International Journal of Economics \& Business Administration (IJEBA), 8(4), 288-298.

Urbancova H. 2013. Competitive Advantage Achievement through Innovation and Knowledge. Journal of Competitiveness, 5(1), 82-96. DOI:

10.7441/joc.2013.01.06 